\title{
Minimizing effect of land degradation in Benue State for sustainable food production
}

\author{
Chagbe Kurayemen ${ }^{1}$, Gyata B. A $^{2}$, Ali Emmanuel ${ }^{2}$ \\ ${ }^{1}$ Department of Agricultural Education, College of Education, Katsina Ala, Nigeria \\ ${ }^{2}$ Department of Soil Science, Institute of Land Resources Jos, Nigeria
}

\begin{abstract}
This paper looks at land degradation and its effects on the environment globally and locally. Unless land rehabilitation measures are effective, a downward eco-social spiral is created when marginal lands are physically, chemically and biologically depleted by unsustainable land management practices resulting in lost soil resilience leading to soil degradation and permanent damage .The paper examines the land degradation types prevalent in Benue state to include: Deforestation, Overexploitation for fuel wood, overgrazing, agricultural activities and industrialization. and the severity with which they occur. The paper concludes that a multidisciplinary approach should be adopted to include effective teaching and learning of environmental education and development of sound policies that can begin the process of healing the land with its attendant benefits to the environment and agricultural revival in Benue state.
\end{abstract}

Keywords: Land- Degradation- sustainability agriculture; Benue state

\section{INTRODUCTION}

In the last two decades, public interest in land quality has been increasing throughout the world as humankind recognizes the fragility of earth's soil, water and air resources, and the need of their protection to sustain civilization. The concept of soil quality was first suggested in 1977 at a conference (Doran and Parkin 1994) which focused on the risks and benefits associated with intensive agriculture, but the concept per se was not discussed until 1980s when it was defined based on the soil function, and the methods to evaluate it were published.

Land and soil quality were usually used interchangeably and were defined in many different ways. Power and Meyers (1989) defined soil quality as the ability of soil to support crop growth, including factors such as tilth, aggregation, organic matter content, soil depth, water holding capacity, infiltration rate, $\mathrm{pH}$ changes and nutrient capacity. Larson and Pierce (1991) defined soil quality as the capacity of the soil to function within ecosystem boundaries and to interact positively with the environment external to that ecosystem.

Land degradation is a concept in which the value of the biophysical environment is affected by one or more contribution of human induced processes upon the land. (Eswaren 2000). (Evans, 2002).defined Land degradation as a decline in the productive ability of the soil.

The world's productive croplands are in decline due to the pressure of human activities. The soil which is very fundamental to agricultural production is a dynamic and natural body composed primarily of weathered material, along with water, oxygen and organic materials. 
Soil, a key element of land resource is a vital natural resource that is nonrenewable on the human time scale (Jenny 1980) and is a living, dynamic, natural body that plays many key roles in terrestrial ecosystems. It is the essence of life and health for the well-being of humankind and animals and the major source of most of our food production. The soil covers most of the land surface with a fragile, thin mantle. Soil organic carbon (SOC) is the most often reported attribute and is chosen as the most important indicator of soil quality and agricultural sustainability. (Lal, 1994).

The soil is layered into sections called "horizons". The layered nature of soil indicates its long evolution under the effects of atmospheric and biological process. The process that creates soil from bare rock is called "weathering". In the weathering process, the atmosphere and water interact with bare rock/parent material to slowly break down parent material into smaller particles which eventually mix up with other organic substances and undergo physical as well as chemical transformation to become soil. This process is slow and complex. It is very difficult to restore lost mantle.

The process of land degradation could be physical, chemical and biological (Obi, 2010). It could take the form of structural deformation, e.g. crusting, accelerated erosion, imbalance in water to air ratio which could impede root penetration and development. Chemical degradation could include processes such as fertility depletion, laterization sodification, aluminum toxicity which can course serious toxicity or limit the ability of plant to pick up needed nutrients in the soil. The biological degradation could include decline in soil organic matter, soil biomass content and alteration is biological process in the soil.

\section{Causes of land degradation}

Productive lands of the world have been on a decline at an alarming rate. Degradation and desertification have been reported by many (Dregne, 1994). Mbagwu, J.S lal, R and Scott, T.W (1984) reported a number of factors, many or most of which are tied to human development. Mackenzie and Mackenzie (1995) identified primary causes of land degradation to include: Deforestation, Overexploitation for fuel wood, overgrazing, agricultural activities and industrialization. Obi, (2010) identified factors such as: excessive cultivation, untimely cultivation, indiscriminate and excessive use of chemicals, intensive row cropping, monoculture and high stocking rate as majour contributors to land degradation in Africa.

On the global basis, soil degradation is caused primarily by Overgrazing (35\%), agricultural activities (28\%), deforestation (30\%), overexploitation of land to produce fuel wood (7\%) and industrialization (4\%). (Mackenzie and Mackenzie 2004).

The patterns are different with various regions of the world. The economic reasons for these processes are complex and are linked to the particular characteristics of each region.

\section{Land degradation types in Benue State.}

Benue State is within the Southern Guinea Savanna agro-ecological zone of Nigeria which is characterized by distinct wet and dry season. The mean annual rainfall is about 1137 $\mathrm{mm}$, with a distribution between April to October. The landform is moderately undulating. The total average evapo-transpiration is estimated at about $2,602 \mathrm{~mm}$ with mean annual relative humidity of about 40.7 percent.(BENSEEDS)

The people of the state are principally engaged in agricultural activities. This activities account for a greater percentage of the degradation types which may be summed up to include: 


\section{(a) Erosion:}

Because of the clearing away of the surface cover/vegetation in order to produce food and cash crops, the surfaces of the soils are usually left bare and the rate of surface runoff increases leading to wearing away of land surface which lead to reduced fertility of the soils. Since the top soils are the richest in soil nutrients and organic matter content. This could be noticed more in the resultant gullies at the southern parts of Benue State e.g. Otukpo, Otukpa and Ugbokolo.

Siltation and accumulation of silt particles in streams and rivers in most part of Benue State are also common as a result of water erosion.

(b) Organic matter depletion:

Constant bush burning activities coupled with rapid mineralization of organic matter is a common feature of low income agriculture especially in the tropics. This leads to rapid organic matter depletion. Organic matter is the storehouse of nutrients and a soil modification material. It's depletion causes impoverishment of soil nutrient status and consequently increases the vulnerability of the soil to crumbling and detachment and transport. It is evident that the most croplands in the state are unproductive today due to this phenomenon.

\section{(c) Desertification:}

Naturally most parts of Benue State belong to a derived Savanna region. The constant felling of trees has generated lush regeneration of grasses over time. However, the encroachment on marginal lands due to loss of fertile and productive lands because of the quest to increase productivity and also because of demand for fuel wood and timber, certain parts of Benue State are excessively deforested and are prone to desertification and its attendant effect.

\section{(d) Acidification / Salinization:}

Although no serious report of Salinization has been reported in Benue State, the downward and lateral transport of soil nutrients in solution due to high torrential rainfall intensity in this region causes soil acidification to crop fields across state resulting to poor crop yields. The high evapo-transpiration which sometime exceeds precipitation is also potentially a Salinization process.

\section{(e) Compaction / Crusting:}

Ivara, (2005) classified soils of Benue valley to consist of Alfisols, Entisols, and Ultisols. These soils are Shallow with underlying clay accumulations and poor internal drainage. These soils also may contain plinthite sub-surface layers and sometimes protrude to surfaces of soils as out-crops.

Because of poor internal drainage of these major soils, infiltration is reduced and in periods of high temperature and evapo-transpiration, soil crusting can become an easy feature on some croplands in Benue State.

Compaction on the other hand could be due to the overgrazing and overstocking. The lush vegetation in Benue State is suitable for grazing of animals especially cattle, resulting in annual grazing. 


\section{EFFECTS OF LAND DEGRADATION}

The main outcome of land degradation is a substantial reduction in the productivity of the land. The major stresses on vulnerable land include as identified by Singer and Ewing (2000) include:

* Accelerated soil erosion by wind and water

* Soil acidification or alkalinisation

* Salination

* Destruction of soil structure including loss of organic matter

* Derelict soil

A picture of the combined effect of land degradation can be seen from the following tables:

Table 1. Estimates of all degraded lands (in million $\mathrm{km}^{2}$ ) in dry areas (Dregne and Chou, 1994).

\begin{tabular}{|c|c|c|c|}
\hline Africa & 14.326 & 10.458 & 73 \\
\hline Asia & 18.814 & 13.417 & 71 \\
\hline Australia and the Pacific & 7.012 & 3.759 & 54 \\
\hline Europe & 1.456 & 0.943 & 65 \\
\hline North America & 5.782 & 4.286 & 74 \\
\hline South America & 4.207 & 3.058 & 73 \\
\hline Total & $\mathbf{5 1 . 5 9 7}$ & $\mathbf{3 5 . 9 2 2}$ & $\mathbf{7 0}$ \\
\hline
\end{tabular}

Table 2. Estimates of the global extent (in million $\mathrm{km}^{2}$ ) of land degradation (Oldeman, 1994).

\begin{tabular}{|c|c|c|c|c|}
\hline Water erosion & 3.43 & 5.27 & 2.24 & 10.94 \\
\hline Wind erosion & 2.69 & 2.54 & 0.26 & 5.49 \\
\hline Chemical degradation & 0.93 & 1.03 & 0.43 & 2.39 \\
\hline Physical degradation & 0.44 & 0.27 & 0.12 & 0.83 \\
\hline Total & $\mathbf{7 . 4 9}$ & $\mathbf{9 . 1 1}$ & $\mathbf{3 . 0 5}$ & $\mathbf{1 9 . 6 5}$ \\
\hline
\end{tabular}

According to (Adejuwon, 2004) the main cause of land degradation in forested and guinea savannah regions is overcutting of vegetation . this occurs when people cut forests, woodlands and shrublands - to obtain timber, fuelwood and other products - at a pace exceeding the rate of natural regrowth. Overgrazing is the grazing of natural pastures at stocking intensities above the livestock carrying capacity; the resulting decrease in the 
vegetation cover is a leading cause of wind and water erosion. In Benue however water erosion is more prevalent. Agricultural activities that can cause land degradation include shifting cultivation without adequate fallow periods, absence of soil conservation measures, and cultivation of fragile or marginal lands, unbalanced fertilizer use, and a host of possible problems arising from faulty planning or management of irrigation. (Aina, nd.).

The role of population factors in land degradation processes obviously occurs in the context of the underlying causes. In the region, in fact, it is indeed one of the two major basic causes of degradation along with land shortage, and land shortage itself ultimately is a consequence of continued population growth in the face of the finiteness of land resources.

Population pressure also operates through other mechanisms. Improper agricultural practices, for instance, occur only under constraints such as the saturation of good lands under population pressure which leads settlers to cultivate too shallow or too steep soils, plough fallow land before it has recovered its fertility, or attempt to obtain multiple crops by irrigating unsuitable soils.

Severe land degradation affects a significant portion of the earth's arable lands, decreasing the wealth and economic development of nations. Land degradation cancels out gains advanced by improved crop yields and reduced population growth. As the land resource base becomes less productive, food security is compromised and competition for dwindling resources increases, the seeds of famine and potential conflict are sown. Unless land rehabilitation measures are effective a downward eco-social spiral is created when marginal lands are nutrient depleted by unsustainable land management practices resulting in lost soil resilience leading to soil degradation and permanent damage.

The effects of land degradation often significantly affect receiving water courses (rivers, wetlands and lakes) since soil, along with nutrients and contaminants associated with soil, are delivered in large quantities to environments that respond detrimentally to their input. Land degradation therefore has potentially disastrous effects on lakes and reservoirs that are designed to alleviate flooding, provide irrigation, and generate hydroelectricity

\section{CONCLUSION AND RECOMMENDATION}

The dynamic processes that influence soil quality are complex, and they operate through time at different locations and situations. The key to soil quality renewal and preservation lies in soil organic matter balance and appropriate land use Soil organic matter is both a source of carbon release and a sink for carbon sequestration. Cultivation and tillage can reduce and change the distribution of soil organic matter while an appropriate crop rotation can increase or maintain the quantity and quality of soil organic matter, and improve soil chemical and physical properties. The return of crop residues and the application of manure and fertilizers can all contribute to an increase in soil quality.,

There is also a need to address land degradation issues though a multidisciplinary approach one of which is the effective teaching-learning of environmental education in our schools. In so doing the socio-economic aspects e.g. poverty reduction will go a long way in minimizing environmental components which impact negativity on land such as overexploitation of fuel wood and indiscriminate felling of trees (deforestation).

The scientific community should also be encouraged to mount integrated programmes for standard methods, data collection and research network for assessment and monitoring of soil and land degradation which are site specific 
The impact of land degradation is a global phenomenon; Benue State which is the food basket of Nigeria is not immune to this menace. It is therefore recommended that appropriate agricultural activities and management techniques which include organic farming, conservation tillage practice, will promote the health of Benue Soils and reduce degradation of our soils and avoid catastrophic effects of this menace.

\section{References}

[1] Adejuwon S.A (2004). "The impacts of climate variability and climate change on cropyield in Nigeria". Paper presented at stakeholders' workshop on assessment of impacts and adaptation to climate change Obafemi Awolowo University, Ile Ife, Nigeria

[2] Aina, P.O. (nd) Rainfall run-off management techniques for erosion control and soil moisture conservation. FAO. Co-operate document repository. http://www.fao.org//docrep.

[3] Dregne, H.E. \& Chou, N.T. (1994). Global desertification dimensions and cost. In Degradation and Restoration of Arid Lands Technical University of Texas.

[4] Doran J.W., Parkin T.B. (1994): Defining and assessing soil quality. In: Doran J.W. et al. (eds.): Defining Soil Quality for a Sustainable Environment. SSSA Spec. Publ. No. 35, ASA and SSSA, Madison, WI: 3-21.

[5] Eswaren, H. (2000) Desertification: A global assessment and risk to sustainability. Proceedings of the $16^{\text {th }}$ International Congress of Soil Science, Motpellier France. 77 , $1-18$.

[6] Evans, R. (2002) Rural land use in England and Whales and the delivery to adjacent Seas of nitrogen, phosphorus and atraizine. Soil use Management 19, 1-7.

[7] Jenny H. (1980): The Soil Resource: Origin and Behavior.Ecol. Stud. 37. SpringerVerlag, New York

[8] Ivara, E.E (2005). Characterization, Classification and Management of Nigerian Soils. $26^{\text {th }}$ inaugural lecture, University of Calabar.

[9] Lal, R. (1994) Tillage effects on land degradation, soil resilience, soil quality and sustainability. Soil tillage Research 27, 1-8.

[10] Larson, W.E., Pierce, F.J. (1991): Conservation and enhancement of soil quality. In: Mumanski J. et al. (eds.): Evaluation for Sustainable Land Management in the Developing World. Vol. 2. Techn. Pap. In: Proc. Int. Workshop, Chiang Rai, Thailand, Int. Board Soil Res. Manage. Bangkok: 175-203.

[11] Mackerizie, F.T. and J.A. Mackarizie (1995) our changing Earth: An introduction to Earth system science and Global Environmental change. Prentice Hall.

[12] Mbagwu, J.S. Lal, R. and Scott, T.W. (1994) Effect of desurfacing of Alfisols and Ultisols in Southern Nigeria. Soil Science society of America Journal, 48, 828-833.

[13] Obi, M.I. (2010). A compendium of Lecture notes on Soil conservation Unpublished.

[14] Oldeman, L.R. (1994). The global extent of Land degradation in: Land Resilience and Sustainable Land Use, ed. Greenland D.J. 99-118. Willingford: CABI. 
[15] Power, J.F., Meyers, R.J.K. (1989): The maintenance or improvement of farming systems in North America and Australia. In: Stewart J.W.B. (ed.): Soil quality in semiarid agriculture. In: Proc. Int. Conf. Univ. Saskatchewan, Saskatoon, Canada: 273-292.

[16] Singer, M.J., Ewing, S.A. (2000): Soil quality. In: SumnerM.E. (ed.): Handbook of Soil Science. CRC Press, Inc., Boca Raton, FL: 271-298.

[17] Tomáš Hes, Anna Poledňáková, International Letters of Social and Humanistic Sciences 2 (2013) 18-31.

[18] Mohsen Mehrara, Masoumeh zirak, International Letters of Social and Humanistic Sciences 2 (2013) 32-38.

[19] Taiwo Adewale Muritala, Ismail O. Fasanya, International Letters of Social and Humanistic Sciences 2 (2013) 39-50.

[20] Borowski A., International Letters of Social and Humanistic Sciences 3 (2013) 46-53.

[21] Borowski A., International Letters of Social and Humanistic Sciences 3 (2013) 69-74.

[22] Donovan A. McFarlane, International Letters of Social and Humanistic Sciences 4 (2013) 35-44.

[23] Rajesh K. Yadav, Nishant Dabhade, International Letters of Social and Humanistic Sciences 4 (2013) 49-69.

[24] Borowski A., International Letters of Social and Humanistic Sciences 4 (2013) 70-74.

[25] Paul Bukuluki, International Letters of Social and Humanistic Sciences 5 (2013) 27-44.

[26] Mohsen Mehrara, Maysam Musai, International Letters of Social and Humanistic Sciences 5 (2013) 55-62.

[27] Debiprasad Mukherjee, International Letters of Social and Humanistic Sciences 6 (2013) 41-48.

[28] Tomáš Hes, Alena Neradová, Karel Srnec, International Letters of Social and Humanistic Sciences 7 (2013) 55-75.

[29] Kinga Dziwańska, International Letters of Social and Humanistic Sciences 7 (2013) 96-112.

[31] Borowski A., International Letters of Social and Humanistic Sciences 7 (2013) 113-118.

[32] Mohsen Mehrara, Maysam Musai, International Letters of Social and Humanistic Sciences 8 (2013) 1-7.

[33] Jacek Tittenbrun, International Letters of Social and Humanistic Sciences 11 (2013) $10-34$.

[34] Mohsen Mehrara, Hamid Abrishami, Mostafa Boroujli, Mahan Amin, International Letters of Social and Humanistic Sciences 11 (2013) 76-83.

[35] Borowski A., International Letters of Social and Humanistic Sciences 11 (2013) 100-105.

[36] Sele Sylvester Ebisin, International Letters of Social and Humanistic Sciences 2 (2014) $1-9$.

[37] Tittenbrun J., International Letters of Social and Humanistic Sciences 2 (2014) 20-40. 
[38] Borowski A., International Letters of Social and Humanistic Sciences 2 (2014) 110-121.

[39] Pawa Tersoo, International Letters of Social and Humanistic Sciences 3 (2014) 26-36.

[40] Rabi'u Muhammad Ishaq, International Letters of Social and Humanistic Sciences 3 (2014) 37-44.

[41] Adoga James Ada, International Letters of Social and Humanistic Sciences 3 (2014) 45-52.

[42] Bahram Meihami, Hussein Meihami, International Letters of Social and Humanistic Sciences 3 (2014) 80-91.

[43] Onyike Maggaret Odu, International Letters of Social and Humanistic Sciences 4 (2014) 31-39.

[44] Uloma Charity Oguzor, International Letters of Social and Humanistic Sciences 4 (2014) 97-104.

[45] Okezie A. Ihugba, Alex Odii, A. C. Njoku, International Letters of Social and Humanistic Sciences 5 (2014) 21-34.

[46] Okezie A. Ihugba, Bankoli Bankong, N. C. Ebomuche, International Letters of Social and Humanistic Sciences 5 (2014) 92-113. 